\title{
Profitabilitas, Kepemilikan Manajerial, Kebijakan Dividen dan Nilai Perusahaan
}

\section{Anak Agung Gede Alit Pramana Putra ${ }^{1}$ \\ Fakultas Ekonomi dan Bisnis \\ Universitas Udayana, Indonesia}

\author{
Gerianta Wirawan Yasa ${ }^{2}$ \\ Fakultas Ekonomi dan Bisnis \\ Universitas Udayana, Indonesia
}

Surel: gungalitpramana11@gmail.com

\section{ABSTRAK}

Tujuan penelitian untuk memberikan bukti empiris mengenai pengaruh rasio keuangan dan non keuangan pada nilai perusahaan. Penelitian ini dilakukan pada perusahaan subsektor kontruksi bangunan di Bursa Efek Indonesia (BEI). Jumlah sampel yang diambil sebanyak 32 sampel amatan, dengan metode nonprobability sampling khususnya teknik pengambilan sampel yaitu purposive sampling. Pengumpulan data dilakukan dengan observasi non participant. Teknik analisis yang digunakan adalah teknik analisis regresi linear berganda. Hasil analisis menunjukkan bahwa profitabilitas, kepemilikan manajerial dan kebijakan dividen berpengaruh positif pada nilai perusahaan subsektor kontruksi bangunan di Bursa Efek Indonesia pada peiode 2016-2019.

Kata Kunci: Nilai Perusahaan; Profitabilitas; Kepemilikan Manajerial; Dividen.

\section{Profitability, Managerial Ownership, Dividend Policy and Firm Value}

\section{ABSTRACT}

The purpose of this study is to provide empirical evidence regarding the effect of financial and non-financial ratios on firm value. This research was conducted on a building construction sub-sector company on the Indonesia Stock Exchange (IDX). The number of samples taken was 32 observational samples, with non-probability sampling method, especially the sampling technique, namely purposive sampling. Data collection is done by non-participant observation. The analysis technique used is multiple linear regression analysis technique. The results of the analysis show that profitability, managerial ownership and dividend policy have a positive effect on the value of the building construction sub-sector companies on the Indonesia Stock Exchange in the 2016-2019.

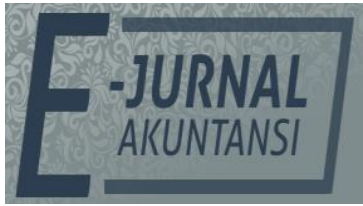

e-ISSN 2302-8556

Vol. 31 No. 8

Denpasar, Agustus 2021 Hal. 2142-2155

DOI:

10.24843/EJA.2021.v31.i08.p20

PENGUTIPAN:

Putra, A.A.G.A.P., \& Yasa, G.W. (2021). Profitabilitas, Kepemilikan Manajerial, Kebijakan Dividen dan Nilai

Perusahaan. E-Jurnal Akuntansi, 31(8), 2142-2155

RIWAYAT ARTIKEL: Artikel Masuk: 17 Mei 2021 Artikel Diterima: 7 Juli 2021

Keywords: $\quad$ Firm Value; Profitability; Managerial Ownership; Dividend.

Artikel dapat diakses : https://ojs.unud.ac.id/index.php/Akuntansi/index 


\section{PENDAHULUAN}

Nilai perusahaan suatu hal yang sangat penting karena ketika nilai perusahaan tinggi akan disertai oleh tingginya kesejahteraan pemegang saham. Semakin tinggi harga saham semakin tinggi nilai perusahaan. Kekayaan pemegang saham dan perusahaan direpresentasikan oleh harga pasar saham. Nilai perusahaan menunjukkan kepercayaan pasar terhadap perusahaan, di mana peningkatan kepercayaan tersebut diindikasikan dengan harga saham di atas nilai buku akibat apresiasi pasar. Sebaliknya, turunnya kepercayaan pasar terhadap perusahaan dapat dilihat dari harga saham dibawah nilai bukunya (Putu et al., 2014).

Fenomena yang terjadi terkait dengan nilai perusahaan adalah perusahaan Salim Group yang bergerak di bisnis sektor barang konsumsi yang diperkirakan memiliki prospek bagus. Beberapa tahun terakhir Salim Group menambah asset lewat akuisisi saham dan ekspansi bisnis. Pada tahun 2014 Holding usaha yang Salim Group, PT Indofood Sukses Makmur Tbk (INDF) memperoleh penjualan bersih Rp63,59 triliun naik 14,3 persen dibandingkan penjualan 2013. Pencapaian menghasilkan laba bersih 3,89 triliun naik 55,2 persen dari tahun 2013. Kemampuan perusahaan dalam menjaga labanya memberikan sinyal positif terhadap nilai perusahaannya. Menurut analisis investasi Group Salim dan Astra sangat likuid sehingga menarik untuk investasi jangka panjang. Selain itu pada Tahun 2018 Salim Group juga mengandeng Madco untuk akusisi 60 persen saham Hyflux Ltd dari Singapura. Perusahaan mengambil pendekatan jangka panjang untuk menambah nilai perusahaan di mata investor (Binsasi, 2018).

Fenomena lain yang berhubungan dengan nilai perusahaan adalah kasus PT Fast Food Indonesia Tbk (FAST). Jelang akhir tahun 2016 perusahaan merealisasi pencairan utang dari pasar lewat penerbitan obligasi. Rencana perusahaan mengelola resto cepat saji KFC di Tanah air dengan surat utang 200 Miliar. Dana tersebut digunakan untuk menggembangkan usaha dan ekspansi. Pembayaran bunga lancar selama periode 2016-2017. FAST akhirnya memperoleh pertumbuhan laba bersih 55,79 persen dengan pendapatan perseroaan tercatat Rp2,31 triliun atau naik 11,05 persen dibandingkan tahun sebelumnya. Hal ini direspon oleh pasar dengan meningkatnya harga saham perusahaan yang menunjukkan peningkatan nilai perusahaan (Quddus, 2016). Naiknya harga saham tersebut dikarenakan adanya faktor-faktor yang mempengaruhi nilai perusahaan. Menurut Amirya \& Atmini (2007) faktor yang dapat mempengaruhi nilai perusahaan adalah kebijakan dividen, profitabilitas, pertumbuhan penjualan, dan ukuran perusahaan.

Penelitian yang dilakukan Husna \& Rahayu (2020) yang bertujan untuk membuktikan secara empiris pengaruh pertumbuhan perusahaan, profitabilitas dan kebijakan dividen terhadap nilai perusahaan. Hasil penelitian berhasil menunjukkan profitabilitas dan kebijakan dividen berpengaruh positif pada nilai perusahaan. telah melakukan penelitian yang bertujuan untuk memberikan bukti empiris pengaruh pertumbuhan perusahaan, kebijakan dividen, dan profitabilitas terhadap nilai perusahaan dengan hasil pertumbuhan perusahaan berpengaruh positif signifikan terhadap nilai perusahaan, kebijakan dividen tidak berpengaruh terhadap nilai perusahaan dan profitabilitas berpengaruh positif dan signifikan terhadap nilai perusahaan. Sedangkan penelitian (Lesmana et al., 2020) yang 
dilakukan pada pengaruh kinerja keuangan terhadap nilai perusahaan menunjukkan hasil penelititian bahwa kinerja keuangan yang meliputi return on assets berpengaruh terhadap nilai perusahaan, return on equity berpengaruh negatif terhadap nilai perusahaan.

Penelitian-penelitian terdahulu tersebut masih menghasilkan hasil yang tidak konsisten. Penulis menduga inkonsistensi itu terjadi karena adanya perbedaan sampel dan kondisi pasar pada saat periode yang digunakan. Lesmana et al., (2020) menyarankan untuk menambah variabel independen selain dari kinerja keuangan. Penelitian ini menggunakan variabel kepemilikan manajerial sebagai variabel selain dari kinerja keuangan.

Pada penelitian ini menggunakan rasio profitabilitas, Suatu perusahaan haruslah berada dalam keadaan yang menguntungkan (profitable), karena tanpa adanya keuntungan akan sulit bagi perusahaan untuk menarik modal dari luar perusahaan atau investor (Zuhroh, 2019). Perusahaan yang memiliki tingkat profitabilitas yang tinggi akan diminati sahamnya oleh investor, sehingga profitabilitas dapat mempengaruhi nilai perusahaan. Profitabilitas memiliki pengaruh yang positif terhadap nilai perusahaan. Profit yang tinggi akan memberikan indikasi prospek perusahaan yang baik sehingga dapat memicu investor untuk ikut meningkatkan permintaan saham. Permintaan saham yang meningkat tentunya akan menyebabkan nilai perusahaan yang meningkat pula (Husna \& Satria, 2019).

Profitabilitas merupakan salah satu faktor yang secara teoritis menentukan nilai suatu perusahaan. Perusahaan yang mampu menghasilkan laba yang tinggi dan stabil akan menarik para investor untuk menanamkan sahamnya pada perusahaan, karena secara langsung akan menguntungkan bagi investor. Kemampuan perusahaan yang besar untuk menghasilkan laba juga menunjukkan manajemen perusahaan yang baik, sehingga menumbuhkan kepercayaan pada investor. Kepercayaan investor ini pada akhirnya dapat menjadi instrumen yang paling efektif untuk meningkatkan harga saham perusahaan. Peningkatan harga saham sama artinya meningkatkan nilai perusahaan, sehingga lebih lanjut dapat menjamin kemakmuran pemegang saham (Lubis et al., 2017). Pengelolaan sumber dana secara efektif oleh pihak manajemen perusahaan akan meningkatkan laba bersih perusahaan. Korespondensi yang menyatakan kemampuan perusahaan dalam menghasilkan keuntungan bersih untuk pengembalian ekuitas pemegang saham adalah Return On Equity. Para investor akan peduli pada perusahaan yang dapat menghasilkan keuntungan yang lebih tinggi sehingga investor akan melakukan penanaman modal ke perusahaan tersebut.

Hal ini didukung oleh penelitian Rudangga \& Sudiarta (2016), Widyantari \& Yadnya (2017), Sihotang \& Saragih (2017) yang menyatakan bahwa profitabilitas mempengaruhi nilai perusahaan secara positif. Berbeda dengan penelitian Atmikasari et al., (2020) yang mengatakan bahwa profitabilitas tidak mempengaruhi nilai perusahaan. Hasil lain yaitu penelitian oleh Sitepu \& Wibisono (2015) yang mengatakan profitabilitas mempengaruhi nilai perusahaan secara negatif.

Kepemilikan manajerial, dimana pihak manajemen sebagai pemilik perusahaan untuk ikut dilibatkan dalam pengambilan keputusan di perusahaan 
tersebut (Marhaeningtyas \& Hartono, 2020). Menurut Ardianti et al., (2019), kepemilikan manajerial akan menyelesaikan masalah keagenan karena pihak manajemen juga memiliki saham perusahaan, sehingga konflik kepentingan antara manajemen dan pemilik terselesaikan. Tidak adanya konflik antara prinsipal dan agen maka akan dapat meningkatkan kinerja keuangan karena adanya keselarasan pemikiran. Kepemilikan institusional dapat mengurangi konflik keagenan sehingga dapat meningkatkan nilai perusahaan (Ratnawati \& Azhari, 2018). Keselarasan kepentingan antara manajer dan pemegang saham dapat diindikasikan dengan proporsi serta besar kecilnya kepemilikan manajerial. Semakin besar proporsi kepemilikan saham oleh manajer pada perusahaan, maka manajer cenderung berusaha lebih giat untuk meningkatkan kinerja keuangan perusahaannya.

Berdasarkan penelitian yang telah dilakukan oleh Abdolkhani \& Jalali (2013), kepemilikan manajerial mempengaruhi nilai perusahaan secara negatif. Namun penelitian tersebut tidak selaras dengan penelitian Pasaribu et al., (2016) yang mengatakan bahwa kepemilikan manajerial mempengaruhi nilai perusahaan secara positif. Hal ini berbeda dengan Febyani \& Devie (2017), yang menyatakan bahwa kepemilikan manajerial tidak mempengaruhi nilai perusahaan. Nilai perusahaan dapat dilihat dari kemampuan perusahaan membayar dividen. Pendistribusian laba berupa dividen atau penahanan laba untuk pendanaan proyek di masa depan disebut kebijakan dividen. Kebijakan dividen adalah suatu keputusan guna menentukan apakah laba yang diperoleh perusahaan akan dibagikan kepada investor sebagai dividen atau akan ditahan dalam bentuk laba ditahan guna pembiayaan investasi di masa mendatang. Apabila perusahaan memilih untuk membagikan dividen maka tingkat pertumbuhan akan berkurang sehingga berdampak negatif terhadap saham perusahaan. Apabila perusahaan tidak membagikan dividen maka pasar akan memberikan sinyal negatif terhadap prospek perusahaan sehingga peningkatan dividen memberikan sinyal perubahan yang menguntungkan pada harapan manajer dan penurunan dividen menunjukkan sinyal negatif pada prospek perusahaan di masa yang akan datang (Aharony \& Swary, 1980).

Kebijakan dividen tetap menjadi salah satu kebijakan keuangan terpenting untuk sebuah perusahaan. Kebijakan dividen membawa informasi tentang prospek perusahaan untuk pertumbuhan laba di masa depan dan informasi tersebut dapat mengundang respondari investor sehingga akan memengaruhi nilai perusahaan (Chandra et al., 2017). Para investor memiliki tujuan utama untuk meningkatkan kesejahteraan dengan mengharapkan pengembalian dalam bentuk dividen maupun capital gain. Seorang investor yang tidak bersedia berspekulasi akan lebih memilih dividen dari pada capital gain.

Besarnya dividen ini dapat memengaruhi harga saham. Apabila dividen yang dibayar tinggi, maka harga saham cenderung tinggi sehingga nilai perusahaan juga tinggi. Sebaliknya jika dividen yang dibayarkan kecil maka harga saham perusahaan tersebut juga rendah. Kemampuan membayar dividen erat hubungannya dengan kemampuan perusahaan memperoleh laba. Jika perusahaan memperoleh laba yang besar, maka kemampuan membayar dividen juga besar. Oleh karena itu, dividen yang besar akan meningkatkan nilai perusahaan (Nurfauziah \& Harjito, 2016). 
Hasil penelitian yang dilakukan oleh Zuraida (2019) dan Pasaribu et al., (2016) menyatakan bahwa kebijakan dividen mempengaruhi nilai perusahaan secara positif, tetapi berbeda dengan temuan penelitian yang dilakukan oleh Laksmi \& Budiartha (2020) yang mengatakan bahwa kebijakan dividen tidak berpengaruh terhadap nilai perusahaan. Proyek infrastruktur adalah salah satu prioritas Presiden Joko Widodo (Jokowi). Dalam lima tahun terakhir, ia telah beberapa kali meresmikan bangunan infrastruktur baru, mulai dari jalan tol, pelabuhan, hingga bandara. Pemerintah Indonesia di bawah kepemimpinan Jokowi sudah menghabiskan sekitar 350 miliar dolar AS untuk infrastruktur. Arah kebijakan pemerintah yang fokus membangun infrastruktur ini tak pelak berimbas positif perusahaan konstruksi, khususnya BUMN Konstruksi atau Karya yang melantai di Bursa Efek Indonesia (Tirto.id, 2019).

Pembangunan infrastruktur tetap menjadi salah satu prioritas utama dalam agenda pembangunan nasional selama beberapa tahun terakhir. Dalam Kebijakan Fiskal (KEM-PPKF) 2022, pemerintah sudah menyusun alokasi anggaran untuk infrastruktur pada tahun 2022 ditetapkan sebesar Rp 450 triliun. Ini meningkat 7,81\% dari alokasi pada tahun ini yang sebesar Rp 417,4 triliun. Menteri Keuangan Sri Mulyani menyampaikan, di tengah perjuangan pemerintah dalam memulihkan ekonomi Indonesia dari Covid-19, pembangunan infrastruktur juga terus dilanjutkan untuk menutup gap infrastruktur dan meningkatkan kemampuan adopsi teknologi (Kontan.co.id, 2021).

Jokowi mengklaim telah berhasil membangun $947 \mathrm{~km}$ jalan tol, $3.432 \mathrm{~km}$ jalan raya, $39 \mathrm{~km}$ jembatan, 10 bandara, 19 pelabuhan, dan 17 bendungan hanya dalam periode empat tahun. Salah satu emiten konstruksi yang terdampak yaitu Wijaya Karya, melonjak drastis selama Jokowi memimpin. Pada 2018, pendapatan Wijaya Karya menembus Rp31,15 triliun, naik hampir tiga kali lipat dari pendapatan 2014 sebesar Rp12,46 triliun (Tirto.id, 2019). Profitabilitas dari sebuah perusahaan memang biasanya dijadikan salah satu faktor penilaian pasar terhadap perusahaan tersebut. Jika perusahaan memiliki profit yang tinggi, maka akan dinilai baik perusahaan itu oleh pasar, dan sebaliknya jika perusahaan memilik profit yang rendah maka akan dinilai rendah juga oleh pasar karena tidak akan berjalan baik untuk masa yang akan datang. Hasil Penelitian yang dilakukan Widyantari \& Yadnya (2017) dan Sihotang \& Saragih (2017) yang menyatakan bahwa profitabilitas mempengaruhi nilai perusahaan secara positif. Perusahaan yang memiliki profitabilitas yang tinggi, itu menandakan perusahaan berhasil mengelola asset maupun modalnya dalam mendatangkan laba yang dimana akan menarik minat investor untuk berinvestasi.

$\mathrm{H}_{1}$ : Profitabilitas berpengaruh positif pada nilai perusahaan.

Penelitian ini menggunakan penjelasan Teori agensi untuk membantu memperjelas konflik keagenan antara agen dan prinsipal dengan adanya kepemilikian manajerial. Kepemilikan manajerial diharapkan bisa meminimumkan konflik keganenan yang terjadi, dengan menyamakan kepentingan antara agen dan prinsipal. Terjadinya konflik keagenan dianggap bisa mempengaruhi nilai perusahaan. dan berdampak pada penilaian investor nantinya.

Penelitian yang dilakukan Pasaribu et al., (2016) yang mengatakan bahwa kepemilikan manajerial mempengaruhi nilai perusahaan secara positif. Adanya 
kepemilikan manajerial akan membantu menyatukan kepentingan anatara agen dan prinsipal. Dengan demikian tujuan perusahaan bisa tercapai dengan baik. Perusahaan dengan pengelolaan yang baik dikatakan mampu untuk meningkatkan nilai perusahaan. Kepemilikan manajerial adalah situasi dimana manajer memiliki saham perusahaan atau dengan kata lain manajer tersebut sekaligus sebagai pemegang saham perusahaan. Manajer yang sekaligus pemegang saham akan termotivasi meningkatkan nilai perusahaan, karena dengan meningkatnya nilai perusahaan maka nilai kekayaannya sebagai pemegang saham akan meningkat pula (Sulistiono, 2010).

$\mathrm{H}_{2}$ : Kepemilikan manajerial berpengaruh positif pada nilai perusahaan.

Pembagian laba dalam bentuk dividen meningkatkan kesejahteraan pemegang saham yang akan meningkatkan nilai saham tersebut. Teori bird in the hand juga menjelaskan besarnya dividen yang akan dibagikan kepada para pemegang saham akan menigkatkan harga saham. Kebijakan dividen adalah keputusan tentang apakah akan membagi laba atau menahannya untuk diinvestaskan kembali kedalam perusahaan. Namun perusahaan yang membagikan laba atau dividen cenderung akan menaikkan nilai saham itu sendiri. Penelitian yang dilakukan Zuraida (2019) dan Pasaribu et al., (2016) menyatakan bahwa kebijakan dividen mempengaruhi nilai perusahaan secara positif. Karena dimana besarnya dividen yang dibagikan kepada para pemegang saham akan menjadi daya tarik bagi pemegang saham karena sebagian investor cenderung lebih menyukai dividen dibandingkan dengan capital gain karena dividen bersifat lebih pasti.

$\mathrm{H}_{3}$ : Kebijakan dividen berpengaruh positif pada nilai perusahaan.

\section{METODE PENELITIAN}

Penelitian dilakukan pada Perusahaan subsektor building construction di PT Bursa Efek Indonesia (BEI) dengan mengakses situs www.idx.co.id.Objek penelitian ini adalah nilai perusahaan subsektor building construction. Nilai perusahaan pada penelitian diproksikan dengan price to book value (PBV), di mana harga pasar per saham perusahaan akan dibandingkan dengan nilai bukunya sebagai acuan dalam mengambil keputusan berinvestasi. Rumus dari PBV menurut (Brigham \& Houston, 2015:152 ).

$$
\mathrm{PBV}=\frac{\text { Harga Saham }}{\text { Nilai Lembar Saham }} \text {.... }
$$

Profitabilitas pada penelitian ini memilih proksi ROE (Return On Equity) di mana tingginya nilai ROE mencerminkan kemampuan perusahaan secara efektif dalam memanfaatkan sumberdaya yang dimiliki, sehingga semakin tinggi ROE maka akan diikuti naiknya nilai perusahaan. ROE adalah rasio perbandingan antara laba setelah pajak dengan modal sendiri atau modal saham yang digunakan untuk mengukur tingkat pengembalian atas investasi bagi pemegang saham biasa atau pemilik modal (Purwohandoko \& Asandimitra, 2006).

$$
\mathrm{ROE}=\frac{\text { Earning After Taxes }}{\text { Total Equity }}
$$

Kepemilikan manajerial dalam laporan keuangan perusahaan ditunjukkan oleh presentase saham perusahaan yang dimiliki oleh manajer (Kautsar, 2019). Rumus kepemilikan manajerial sebagai berikut. 
Kepemilikan Manajerial $=\frac{\text { kepemilikan saham manajerial }}{\text { total saham yang beredar }}$

Kebijakan dividen merupakan suatu keputusan untuk menentukan berapa besar bagian dari pendapatan perusahaan yang akan dibagikan kepada pemegang saham yang diinvestasikan kembali atau ditahan dalam perusahaan. Dividen adalah jumlah pendapatan yang didistribusikan di antara pemegang saham perusahaan. Dengan kata lain dividen adalah distribusi sisa laba bersih perusahaan yang didistribusikan kepada pemegang saham, dengan persetujuan RUPS. Dalam penelitian ini menggunakan proksi dividen payout ratio yang merupakan perbandingan antara dividen pershare dengan earning pershare.

$\mathrm{DPR}=\frac{\text { Dividen } \text { Per Share }}{\text { Earning Per Share }}$

Populasi dalam penelitian ini adalah 18 (delapan belas) perusahaan yang tergabung dalam subsektor building construction yang terdaftar di Bursa Efek Indonesia. Teknik pengambilan sampel dalam penelitian ini menggunakan purposive sampling. Purposive sampling adalah teknik sampling non random sampling dimana peneliti menentukan pengambilan sampel dengan cara menetapkan ciri-ciri khusus yang sesuai dengan tujuan penelitian sehingga diharapkan dapat menjawab permasalahan penelitian. Adapun kriterianya adalah perusahaan yang terdaftar di BEI, mempunyai data keuangan lengkap dan dapat diandalkan kebenarannya, periode pelaporan keuangan didasarkan pada tahun kalender yang berakhir pada tanggal 31 Desember periode 2016-2019, perusahaan yang membagikan dividen berturut-turut selama periode 2016-2019, perusahaan yang sahamnya aktif diperdagangkan di BEI. Dengan Demikian sampel dalam penelitian ini adalah 8 (delapan) perusahaan subsector building construction pada periode 2016-2019.

Model yang digunakan dalam penelitian ini adalah analisis regresi berganda. Analisis regresi linier berganda ialah suatu analisis dalam ilmu statistik yang berguna untuk mengukur hubungan matematis antara lebih dari 2 variabel bebas $(X)$ dengan variabel penjelas/ dependen $(Y)$. Analisis Regresi dari penelitian ini adalah sebagai berikut:

$$
\mathrm{PBV}=\mathrm{a}+\beta_{1} R O E+\beta_{2} K M+\beta_{3} D P R+\varepsilon
$$

Keterangan:

$$
\begin{array}{ll}
\mathrm{PBV} & =\text { Price To Book Value } \\
\alpha & =\text { Konstanta Atau Konstan } \\
\beta 1-\beta 3 & =\text { Koefisien Regresi } \\
\mathrm{ROE} & =\text { Return On Equity } \\
\mathrm{KM} & =\text { Kepemlikan Manajerial } \\
\mathrm{DPR} & =\text { Dividen Payout Ratio } \\
\varepsilon & =\text { Error }
\end{array}
$$

\section{HASIL DAN PEMBAHASAN}

Rasio Profitabilitas yang diproksikan dengan Return On Equity (ROE) memiliki nilai minimum sebesar $-0,0029$ yang dimiliki oleh perusahaan PT Indonesia Pondasi Raya Tbk pada tahun observasi 2019 dan nilai maksimum sebesar 0,2347 yang dimiliki oleh perusahaan PT. Total Bangun Persada Tbk pada tahun observasi 2016. Hal ini menunjukkan bahwa kisaran profitabilitas perusahaan sampel paling rendah adalah $-0,0029$ dan paling tinggi adalah 0,2347 . Variabel 
profitabilitas memiliki nilai rata-rata sebesar 0,1099 menunjukkan sebagian besar perusahaan yang diteliti memiliki tingkat profitabilitas yang tinggi. Nilai deviasi standar sebesar 0,0543 menunjukkan bahwa terjadi penyimpangan sebesar 0,0543 dari rata-rata variabel profitabilitas. Hasil statistik deskriptif dapat dilhat dari Tabel 1, sebagai berikut.

Tabel 1. Hasil Statistik Deskriptif

\begin{tabular}{llllll}
\hline Variabel & N & Minimum & Maksimum & $\begin{array}{l}\text { Rata- } \\
\text { rata }\end{array}$ & $\begin{array}{l}\text { Deviasi } \\
\text { Standar }\end{array}$ \\
\hline ROE & 32 & $-0,002$ & 0,234 & 0,109 & 0,054 \\
KM & 32 & 0,000 & 0,849 & 0,120 & 0,278 \\
DPR & 32 & 0,020 & 0,730 & 0,344 & 0,217 \\
PBV & 32 & 0,410 & 5,820 & 1,621 & 1,236 \\
\hline
\end{tabular}

Sumber: Data Penelitian, 2021

Kepemilikan Manajerial memiliki nilai minimum sebesar 0,0001 yang dimiliki oleh perusahaan PT. Adhi Karya (Persero) Tbk pada tahun observasi 2016, 2018, 2019 dan nilai maksimum sebesar 0,84925 yang dimiliki oleh perusahaan PT. Indonesia Pondasi Raya Tbk pada tahun observasi 2019. Hal ini menunjukkan bahwa kisaran kepemilikan manajerial perusahaan sampel paling rendah adalah 0,000 dan paling tinggi adalah 0,849 . Variabel kepemilikan manajerial memiliki nilai rata-rata sebesar 0,120 menunjukkan sebagian besar perusahaan yang diteliti memiliki tingkat kepemilikan manajerial yang rendah. Nilai deviasi standar sebesar 0,278 menunjukkan bahwa terjadi penyimpangan sebesar 0,278 dari ratarata variabel kepemilikan manajerial.

Kebijakan Dividen yang diproksikan dengan dividen payout ratio (DPR) memiliki nilai minimum sebesar 0,020 yang dimiliki oleh perusahaan PT. Indonesia Pondasi Raya Tbk pada tahun observasi 2016 dan nilai maksimum sebesar 0,730 yang dimiliki oleh perusahaan PT. Nusa Raya Cipta Tbk pada tahun observasi 2017. Hal ini menunjukkan bahwa kisaran kebijakan dividen perusahaan sampel paling rendah adalah 0,020 dan paling tinggi adalah 0,730. Variabel kebijakan dividen memiliki nilai rata-rata sebesar 0,3441 menunjukkan sebagian besar perusahaan yang diteliti memiliki tingkat kebijakan dividen yang tinggi. Nilai deviasi standar sebesar 0,217 menunjukkan bahwa terjadi penyimpangan sebesar 0,217 dari rata-rata variabel kebijakan dividen.

Nilai Perusahaan yang diproksikan dengan Price Book Value (PBV) memiliki nilai minimum sebesar 0,41 yang dimiliki oleh perusahaan PT. Pembangunan Perumahan (Persero) Tbk pada tahun observasi 2018 dan nilai maksimum sebesar 5,820 yang dimiliki oleh perusahaan PT. Nusa Raya Cipta Tbk pada tahun observasi 2016. Hal ini menunjukkan bahwa kisaran nilai perusahaan dari perusahaan sampel paling rendah adalah 0,410 dan paling tinggi adalah 5,820. Variabel nilai perusahaan memiliki nilai rata-rata sebesar 1,621 menunjukkan sebagian besar perusahaan yang diteliti memiliki tingkat nilai perusahaan yang rendah. Nilai standar deviasi sebesar 1,236 menunjukkan bahwa terjadi penyimpangan sebesar 1,236 dari rata-rata variabel nilai perusahaan.

Hipotesis penelitian diuji dengan menggunakan analisis regresi liner berganda. Analisis regresi linier berganda merupakan teknik statistik melalui koefisiensi parameter untuk mengetahui besarnya pengaruh variabel independen pada variabel dependen. Analisis regresi linier berganda ini diukur dengan 
bantuan program software SPSS 21 for Windows. Hasil analisis regresi linear berganda pada penelitian ini disajikan dalam Tabel 2, sebagai berikut.

Tabel 2. Hasil Analisis Regresi Linear Berganda

\begin{tabular}{|c|c|c|c|c|c|}
\hline \multirow[t]{2}{*}{ Model } & \multicolumn{2}{|c|}{$\begin{array}{l}\text { Unstandardized } \\
\text { coefficients }\end{array}$} & \multirow{2}{*}{$\begin{array}{l}\text { Standardized } \\
\text { coefficients } \\
\text { Beta }\end{array}$} & \multirow[t]{2}{*}{$t$} & \multirow[t]{2}{*}{ Sig. } \\
\hline & $\mathrm{B}$ & Std. Error & & & \\
\hline 1 (Constant) & 1,069 & 0,609 & & 1,756 & 0,090 \\
\hline ROE & 7,983 & 4,651 & 0,351 & 1,716 & 0,007 \\
\hline $\mathrm{KM}$ & 0,434 & 0,861 & 0,098 & 0,504 & 0,016 \\
\hline DPR & 1,098 & 1,078 & 0,193 & 1,019 & 0,013 \\
\hline Variabel Dep & & & & & \\
\hline
\end{tabular}

Sumber: Data Penelitian, 2021

Berdasarkan Tabel 2, terebut diperoleh model regresi berganda yang terbentuk pada penelitian ini dalah sebagai berikut.

$$
\mathrm{PBV}=1,069+7,983 \mathrm{ROE}+0,434 \mathrm{KM}+1,098 \mathrm{DPR}
$$

Nilai konstanta (a) sebesar 1,069 maka dapat diartikan apabila terdapat pengaruh dari variabel lain atau variabel bebas, maka nilai konstan dari variabel nilai perusahaan yang diproksikan dengan PBV adalah sebesar 1,069. Nilai koefisien variabel rasio profitabilitas yang diproksikan dengan ROE yaitu 7,983 memiliki arti bahwa ROE memiliki hubungan positif terhadap nilai perusahaan. Apabila ROE meningkat sebesar satu satuan maka nilai perusahaan (PBV) akan meningkat sebesar 7,983 dengan asumsi variabel bebas lainnya konstan.

Nilai koefisien kepemilikan manajerial (KM) yaitu 0,434 memiliki arti bahwa kepemilikan manajerial memiliki hubungan positif terhadap nilai perusahaan. Apabila kepemilikan manajerial (KM) meningkat sebesar satu satuan maka nilai perusahaan (PBV) akan meningkat sebesar 0,434 dengan asumsi variabel bebas lainnya konstan. Nilai koefisien kebijakan dividen yang diproksikan dengan DPR yaitu 1,098 memiliki arti bahwa kebijakan dividen memiliki hubungan positif terhadap nilai perusahaan. Apabila DPR meningkat sebesar satu satuan maka nilai perusahaan (PBV) akan meningkat sebesar 1,098 dengan asumsi variabel bebas lainnya konstan.

Tabel 2, menunjukkan bahwa profitabilitas yang diproksikan ROE memiliki nilai signifikansi sebesar 0,007 dengan $t_{\text {hitung }}$ bernilai positif sebesar 1,716. Nilai signifikansi variabel sebesar 0,007 lebih kecil dari taraf signifikansi sebesar 0,05 (5 persen) yang mengindikasikan bahwa $\mathrm{H}_{1}$ diterima. Hal ini berarti bahwa secara parsial rasio profitabilitas berpengaruh positif terhadap nilai perusahaan. Hasil pengujian hipotesisi profitabilitas yang diproksikan dengan retun on equity (ROE) menunjukkan hasil yang positif signifikan terhadap nilai perusahaan. Hal ini mendukung hipotesis pertamana mengenai rasio profitabilitas berpengaruh positif terhadap nilai perusahaan, sehingga hipotesis pertama diterima. Penelitian ini sejalan dengan penelitian yang dilakukan Widyantari \& Yadnya (2017) dan Sihotang \& Saragih (2017)mempengaruhi nilai perusahaan secara positif. Berdasarkan Table 1, rata-rata nilai ROE cenderung lebih mendekati nilai maksimum atau dengan kata lain sebagaian besar perusahaan yang diteliti memiliki tingkat rasio profitabilitas yang tinggi. Rasio profitabilitas yang diproksikan dengan ROE jika mengalami peningkatan maka perusahaan semakin 
baik dalam mengelola modalnya untuk medatangkan laba, sehingga dapat menarik investor untuk membeli saham pada perusahaan tersebut.

Hasil penelitian ini juga mendukung Teori Sinyal, yang menyatakan bahwa ada suatu informasi yang dapat mengakibatkan pasar bereaksi. Dalam hal ini informasi perubahan baik itu berupa peningkatan maupun penurunan profitabilitas yang dilihat melalui retun on equity (ROE) pada suatu perusahaan merupakan suatu informasi atau sinyal yang dapat mengakibatkan investor menjual maupun membeli saham suatu perusahaan dan berakibat pada fluktuasi harga saham perusahaan tersebut. Tabel 2, menunjukkan bahwa kepemilikan manajerial $\mathrm{KM}$ memiliki nilai signifikansi sebesar 0,016 dengan $\mathrm{t}_{\text {hitung }}$ bernilai positif sebesar 0,504. Nilai signifikansi variabel sebesar 0,016 lebih kecil dari taraf signifikansi sebesar 0,05 (5 persen) yang mengindikasikan bahwa $\mathrm{H}_{2}$ diterima. Hal ini berarti bahwa secara parsial kepemilikan manajerial berpengaruh positif terhadap nilai perusahaan.

Hasil pengujian hipotesisi menunjukkan kepemilikan manajerial berpengaruh positif pada nilai perusahaan. Penelitian ini sejalan dengan penelitian Pasaribu et al., (2016) yang mengatakan bahwa kepemilikan manajerial mempengaruhi nilai perusahaan. Kepentingan manajer selaku pengelola perusahaan akan dapat berbeda dengan kepentingan pemegang saham. Konflik kepentingan antara manajer dengan pemilik menjadi semakin besar ketika kepemilikan manajer terhadap perusahaan semakin kecil. Sebaliknya, semakin besar kepemilikan manajer didalam perusahaan maka semakin produktif tindakan manajer dalam memaksimalkan nilai perusahaan, dengan kata lain biaya kontrak dan biaya pengawasan menjadi rendah.

Semakin besar kepemilikan manajemen dalam perusahaan, maka manajemen akan cenderung berusaha meningkatkan kinerja untuk kepentingan pemegang saham dan untuk kepentingannya sendiri. Hasil penelitian ini juga mendukung teori keagenan, dimana pada teori keagenan disebutkan bahwa adanya kepemilikan manajeral akan meningkatkan kinerja keungan perusahaan. Kepemlikan ini akan menyejajarkan kepentingan manajemen dengan pemegangsaham (Jensen \& Meckling, 1976). Tabel 2, menunjukkan bahwa kebijakan dividen yang di prokskan dengan DPR memiliki nilai signifikansi sebesar 0,013 dengan $t_{\text {hitung }}$ bernilai positif sebesar 1,019 . Nilai signifikansi variabel sebesar 0,013 lebih kecil dari taraf signifikansi sebesar 0,05 (5 persen) yang mengindikasikan bahwa $\mathrm{H}_{3}$ diterima. Hal ini berarti bahwa secara parsial kebijakan dividen berpengaruh positif terhadap nilai perusahaan.

Hasil pengujian hipotesis menunjukkan kebijakan dividen yang diproksikan dengan dividend payout ratio (DPR) berpengaruh positif pada nilai perusahaan. Penelitian ini sejalan dengan penelitian yang dilakukan oleh Zuraida (2019) dan Pasaribu et al., (2016) kebijakan dividen berpengaruh positif. Berdasarkan tabel 1, rata-rata nilai DPR cenderung lebih mendekati nilai maksimum atau dengan kata lain sebagaian perusahaan yang diteliti memiliki tingkat DPR yang tinggi. Ini menunjukkan para investor lebih menyukai perusahaan yang membagikan dividen karena adanya kepastian tentang return atas investasinya. Semakin besar dividen yang dibagikan oleh perusahaan kepada pemegang saham, maka kinerja perusahaan akan dianggap baik dan perusahaan yang dianggap memiliki kinerja yang baik akan dianggap menguntungkan, sehingga penilaian terhadap 
perusahaan tersebut akan membaik yang dapat tercermin dari tingkat harga saham perusahaan.

Hasil penelitian ini juga mendukung theory bird in the hand dimana pada theory bird in the hand disebutkan investor lebih menyukai dividen tunai dari pada disajikan adanya imbal hasil atas investasi (capital gain) dimasa yang akan datang. Harapan pembayaran dividen saat ini terjadi karena ada anggapan bahwa mendapat dividen saat ini resikonya lebih kecil daripada mendapat capital gain di masa yang akan datang meskipun capital gain di masa mendatang dapat memberikan pengembalian yang lebih tinggi daripada dividen saat ini, selain resiko juga adanya ketidak pastian tentang arus kas perusahaan di masa depan.

Nilai koefisien determinasi $\left(\mathrm{R}^{2}\right)$ menunjukkan seberapa jauh kemampuan variabel bebas dalam menjelaskan variasi variabel terikat. Peneliti menggunakan nilai Adjusted $\mathrm{R}^{2}$ pada saat mengevaluasi manakah model yang terbaik, karena tidak seperti R ${ }^{2}$, nilai Adjusted $\mathrm{R}^{2}$ dapat naik atau turun apabila satu variabel bebas ditambahkan ke dalam model. Hasil uji koefisien determinasi disajikkan dalam Tabel 3, sebagai berikut.

Tabel 3. Hasil Koefisien Determinasi $\left(\mathbf{R}^{2}\right)$

\begin{tabular}{lllll}
\hline Model & $\mathrm{R}$ & $\mathrm{R}$ Square & Adjusted R Square & $\begin{array}{l}\text { Std. Error of the } \\
\text { Estimate }\end{array}$ \\
\hline 1 & 0,320 & 0,103 & 0,106 & 1,232 \\
\hline
\end{tabular}

Sumber: Data Penelitian, 2021

Hasil uji koefisien determinasi dengan Adjusted $\mathrm{R}^{2}$ yang disajikkan dalam Tabel 3, menunjukkan nilai dari Adjusted R2 adalah sebesar 0,106 atau 10,6 persen, dimana memiliki arti bahwa 10,6 persen variansi nilai perusahaan dipengaruhi oleh variansi profitabilitas, kepemilikan manajerial, dan kebijakan dividen, sedangkan sisanya yang sebesar 89,4 persen dijelaskan oleh variabel lain diluar variabel independen. Uji kelayakan model (Uji F) digunakan untuk menunjukkan apakah semua variabel bebas yang dimasukkan dalam model mempunyai pengaruh secara bersama-sama terhadap variabel terikat (Ghozali, 2016:98). Uji F dilakukan dengan membandingkan tingkat signifikansi masing-masing variabel bebas secara bersama-sama dengan taraf signifikannya yaitu a sebesar 5\%. Jika nilai signifikansi uji $\mathrm{F}<0,05$ maka model yang digunakan dalam penelitian ini layak dan dapat dipergunakan untuk analisis berikutnya, begitupun sebaliknya. Adapun hasil uji F tersebut dapat dilihat pada Tabel 4, sebagai berikut.

Tabel 4. Hasil Uji Kelayakan Model (Uji F)

\begin{tabular}{|c|c|c|c|c|c|}
\hline Model & Sum of Square & $d f$ & Mean Square & $\mathrm{F}$ & Sig. \\
\hline $1 \quad$ Regression & 4,861 & 3 & 1,620 & 1,067 & 0,002 \\
\hline Residual & 42,512 & 28 & 1,518 & & \\
\hline Total & 47,373 & 31 & & & \\
\hline
\end{tabular}

Sumber: Data Penelitian, 2021

Hasil uji kelayakan model (Uji F) yang disajikan dalam Tabel 4, dapat dilihat bahwa nilai $F_{\text {hitung }}$ sebesar 1,067 dengan signifikansi sebesar 0,002. Hal ini menunjukkan bahwa signifikansi pada Uji $\mathrm{F}$ nilainya lebih kecil dari 0,05 (5 persen), sehingga dapat disimpulkan bahwa model regresi yang dibuat layak digunakan untuk menjelaskan pengaruh profitabilitas, kepemilikan manajerial, kebijakan dividen terhadap nilai perusahaan. 


\section{SIMPULAN}

Penelitian menghasilkan bukti empiris bahwa profitabilitas yang di proksikan dengan retun on equity $\mathrm{ROE}$ berpengaruh positif dengan nilai perusahaan, hal ini sejalan dengan Teori Sinyal yang menyatakan bahwa ada suatu informasi yang dapat mengakibatkan pasar bereaksi. Dalam hal ini informasi perubahan baik itu berupa peningkatan maupun penurunan profitabilitas yang dilihat melalui retun on equity (ROE) pada suatu perusahaan merupakan suatu informasi atau sinyal yang dapat mengakibatkan investor menjual maupun membeli saham suatu perusahaan dan berakibat pada fluktuasi harga saham perusahaan tersebut.

Penelitian ini juga menghasilkan bukti empiris bahwa kepemilikan manajerial berpengaruh positif pada nilai perusahaan. Hal ini sejalan dengan teori keagenan, dimana pada teori keagenan disebutkan bahwa adanya kepemilikan manajeral akan meningkatkan kinerja keungan perusahaan. Semakin besar kepemilikan manajemen dalam perusahaan, maka manajemen akan cenderung berusaha meningkatkan kinerja untuk kepentingan pemegang saham dan untuk kepentingannya sendiri. Penelitian ini juga mengasilkan bukti empiris bahwa kebijakan dividen berpengaruh positif pada nilai perusahaan. Hasil penelitian ini sejalan theory bird in the hand. Salah satu pertimbangan investor dalam memutuskan untuk membeli saham dari suatu perusahaan adalah informasi pembagian dividen. Dengan pembagian dividen, selain investor mendapatkan keuntungan, investor juga dapat menilai prospek masa depan perusahaan.

Penelitian ini memberikan implikasi praktis bagi perusahaan yang terdaftar di Bursa Efek Indonesia khususnya subsektor building construction dengan hasil uji penelitian ini diharapkan dapat membantu menjadi bahan pertimbangan meningkatkan nilai perusahaan dengan mempertimbangkan pengaruh informasi seperti profitabilitas, kepemilikan manajerial dan kebijakan dividen. Hasil penelitian ini juga diharapkan dapat membantu investor dalam memberikan tambahan referensi informasi keuangan yaitu profitabilitas, kebijakan dividen serta informasi non keuangan kepemilikan manajerial dapat dijadikan dasar dalam menentukan keputusahan investasi saat membeli saham perusahaan. Serta, hasil uji penelitian ini diharapkan dapat menjadi tambahan wacana dan literatur di bidang pasar modal utamanya dalam fenomena pergerakan nilai perusahaan.

\section{REFERENSI}

Abdolkhani, H., \& Jalali, R. (2013). Effect of Managerial Ownership Concentrated on Firm Return and Value: Evidence from Iran Stock Market. International Journal of Academic Research in Accounting, Finance and Management Sciences, $3(1), 46-51$.

Aharony, J., \& Swary, I. (1980). Quarterly Dividend and Earnings Announcements and Stockholder's Returns: An Empirical Analysis. The Journal OfFinance, 35(1), 1-12. https:// doi.org/10.1111/j.1540-6261.1980.tb03466.x

Amirya, M., \& Atmini, S. (2007). Faktor-Faktor Yang Mempengaruhi Nilai Perusahaan Yang Dimediasi Oleh Leverage Perusahaan Sebagai Variabel Intervening: Sebuah Perspektif Pecking Order Theory. The 1 Accounting Conference Faculty of Economics Universitas Indonesia.

Ardianti, Y., Akram, A., \& Surasni, S. (2019). Pengaruh Kepemilikan Manajerial dan Komisaris Independen Terhadap Nilai Perusahaan Dengan CSR sebagai 
Variabel Mediasi. E-Jurnal Akuntansi, 27, 388-402. https://doi.org/10.24843/EJA.2019.v27.i02.p30

Atmikasari, D., Iindrati, I., \& Aditya, E. M. (2020). Pengaruh Profitabilitas terhadap Nilai Perusahaan dengan Kebijakan Deviden sebagai Variabel Intervening. Jurnal Ilmiah Aset, 22(1), 25-34. doi: 10.37470/1.022.1.04

Binsasi, K. de R. (2018). Salim Group gandeng Medco untuk akuisisi 60\% saham Hyflux Ltd dari Singapura.

Brigham, E. F., \& Houston, J. F. (2015). In Essentials of Financial Management 3rd Edition (Singapore:).

Chandra, K., Fachrudin, Sadalia, I., \& Siburian, R. (2017). The Effect of Capital Structure, Profitability and Dividend Policy on Intrinsic Value of Firm. Journal of Finance and Accounting, 8(14), 101-107.

Febyani, E., \& Devie. (2017). Pengaruh Kepemilikan Manajerial Terhadap Nilai Perusahaan Melalui Manajemen Laba Sebagai Variabel Intervening Di Indonesia Pada Perusahaan Yang Terdaftar Di Bursa Efek Indonesia (BEI). Business Accounting Review, 5(2), 745-754.

Ghozali, H. I. (2016). Aplikasi Analisis Multivariate dengan Program IBM SPSS 23 (Edisi Kede). Badan Penerbit Universitas Diponegoro.

Husna, A., \& Satria, I. (2019). Effects Of Return On Asset, Debt To Asset Ratio, Current Ratio, Firm Size, And Dividend Payout Ratio On Firm Value. International Journal of Economics And Financial Issues, 9(5), 50-54. https://doi.org/10.32479/ijefi.8595

Husna, R., \& Rahayu, Y. (2020). Pengaruh Pertumbuhan Perusahaan, Kebijakan Dividen, Dan Profitabilitas Terhadap Nilai Perusahaan. Jurnal Ilmu Dan Riset Akuntansi, 9(1), 1-16.

Jensen, M. C., \& Meckling, W. H. (1976). Theory of the firm: Managerial behavior, agency costs and ownership structure. Journal of Financial Economics, 3(4), 305260. https:// doi.org/10.1016/0304-405X(76)90026-X

Kautsar, A. (2019). The Impact of Ownership Structure on Dividend Payout Property and Construction Companies in Indonesia. International Journal of Academic Research in Economics \& Management Sciences, 8(1), 66-74. http://dx.doi.org/10.6007/IJAREMS/v8-i1/5555

Laksmi, I. A. S. D., \& Budiartha, I. K. (2020). Pengaruh Kebijakan Dividen terhadap Nilai Perusahaan dengan Kebijakan Hutang sebagai Variabel Moderasi. EJurnal Akuntansi, 30(12), 3040-3050. doi: 10.24843/EJA.2020.v30.i12.p04

Lesmana, T., Iskandar, Y., \& Helian. (2020). Pengaruh Kinerja Keuangan Terhadap Nilai Perusahaanpada Perusahaan Rokok Yang Terdaftardi Bei. Proaksi, 2, 2534.

Lubis, I. L., Sinaga, B. M., \& Sasongko, H. (2017). Pengaruh Profitabilitas, Sruktur Modal, Dan Likuiditas Terhadap Nilai Perusahaan. Jurnal Aplikasi Bisnis Dan Manajemen, 3(3), 458-465. https:// doi.org/doi.org/10.17358/jabm.3.3.458

Marhaeningtyas, D., \& Hartono, U. (2020). Kepemilikan manajerial, kebijakan dividen, leverage , profitabilitas, ukuran perusahaan, dan nilai perusahaan (studi pada perusahaan pertambangan di indonesia). Jurnal Ilmu Manajemen Volume 8 Nomor 3 - Jurusan Manajemen Fakultas Ekonomi Universitas Negeri Surabaya, 8 , 1060-1072. https://journal.unesa.ac.id/index.php/jim/article/view/8859 
Nurfauziah, \& Harjito, A. (2016). Hubungan Kebijakan Hutang, Insider Ownership Dan Kebijakan Dividen Dalam Mekanisme Pengawasan Masalah Agensi Di Indonesia. Jurnal Akuntansi Dan Auditing Indonesia, 10(2), 121-136.

Pasaribu, M. Y., Topowijono, \& Sulasmiyati, S. (2016). Pengaruh Struktur Modal, Struktur Kepemilikan Dan Profitabilitas Terhadap Nilai Perusahaan Pada Perusahaan Sektor Industri Dasar Dan Kimia Yang Terdaftar Di Bei Tahun 2011-2014. Jurnal Administrasi Dan Bisnis, 35(154-164).

Purwohandoko, \& Asandimitra. (2006). Manajemen Keuangan 1.

Putu, N. N. G. M., Moeljadi, Djumahir, \& Djazuli, A. (2014). Factors Affecting Firms Value of Indonesia Public Manufacturing Firms. International Journal of Business and Management Invention, 3, 35-44.

Quddus, G. G. (2016). Pengelola gerai KFC akan rilis obligasi Rp 200 M. https:/ / investasi.kontan.co.id/news/pengelola-gerai-kfc-akan-rilisobligasi-rp-200-m

Ratnawati, V., \& Azhari, F. (2018). The Impact of Institutional Ownership and a Firm's Size on Firm Value: Tax Avoidance as a Moderating Variable. JJournal of Finance and Banking Review, 3, 1-8. http://dx.doi.org/10.35609/jfbr.2018.3.1(1)

Rudangga, I. G. N. G., \& Sudiarta, G. M. (2016). Pengaruh Ukuran Perusahaan, Leverage, Dan Profitabilitas Terhadap Nilai Perusahaan. E-Jurnal Manajemen, 5(7), 4394-4422.

https://ojs.unud.ac.id/index.php/Manajemen/article/view/21920

Sihotang, D. R., \& Saragih, J. L. (2017). Pengaruh Kebijakan Dividen, Kebijakan Hutang Dan Profitabilitas Terhadap Nilai Perusahaan Pada Perusahaan Manufaktur Yang Terdaftar Di Bursa Efek Indonesia. Jurnal Riset Akuntansi Dan Bisnis, $3(1)$. https://doi.org/https://dx.doi.org/10.1234/akuntansi.v3i1.439

Sitepu, N. R., \& Wibisono, C. H. (2015). Pengaruh Kebijakan Dividen, Kebijakan Leverage Dan Profitabilitas Terhadap Nilai Perusahaan (Perusahaan Manufaktur Yang Terdaftar Di Bei Pada Tahun 2009-2013). UAJY Library, 115. http:/ / e-journal.uajy.ac.id/id/eprint/8708

Sulistiono. (2010). Pengaruh Kepemilikan Manajerial, Struktur Modal dan Ukuran Perusahaan Terhadap Nilai Perusahaan Pada Perusahaan Manufaktur Di Bei Tahun 2006-2008. UNNES Repository, Skripsi :

Widyantari, N. L. P., \& Yadnya, I. P. (2017). Pengaruh Struktur Modal, Profitabilitas Dan Ukuran Perusahaan Terhadap Nilai Perusahaan Pada Perusahaan Food And Baverage. E-Jurnal Manajemen, 6(12), 6383-6409. https://ojs.unud.ac.id/index.php/Manajemen/article/view/33576

Zuhroh, I. (2019). The Effects of Liquidity, Firm Size, and Profitability on the Firm Value with Mediating Leverage. KnE Social Sciences, 3(13), 203. https://doi.org/10.18502/kss.v3i13.4206

Zuraida, I. (2019). Pengaruh Struktur Modal, Ukuran Perusahaan, Profitabilitas Dan Kebijakan Dividen Terhadap Nilai Perusahaan. Balance Jurnal Akuntansi Dan Bisnis, 4(1), 529-536. 